\title{
PENGARUH BEBAN KERJA DAN BURNOUT (KEJENUHAN KERJA) TERHADAP INTENSI TURNOVER GURU SEKOLAH MENENGAH PERTAMA DI SEKOLAH BERCIRIKAN AGAMA BUDDHA DI DKI JAKARTA
}

\section{Widia Darma1}

Abstract: The objective of the research is find out the effet of workload and burnout on the teacher's intention turnover. the research was conducted at Buddhist junior high school in Jakarta. The research was using a survey method with path analysis applied in the hypothesis and 92 sample selected by simple random sampling. The research techniques is analysis with quantitative research approaches by using causal analysis. The finding of the research are: 1) there is a positive direct effect of workload on turnover intention; 2) there is a positive direct effect of burnout on turnover intention; 3) there is a positive direct effect of workload on burnout.

Keywords: Turnover intention, workload, and burnout

\section{PENDAHULUAN}

Dewasa ini pada kenyataannya, masih begitu banyaknya permasalahan yang harus diselesaikan dan dicarikan solusi terkait dengan pendidikan nasional, khususnya tenaga guru. Mulai dari kesejahteraan guru, kualitas guru, sarana dan prasarana, serta beban kerja guru yang berat yang tidak diimbangi dengan reward serta kesejahteraan guru yang memadai.

Berbagai persoalan yang dihadapi guru inilah, yang kemudian memicu kinerja dan prestasi guru yang tidak maksimal yang kemudian diiringi dengan mutu pendidikan nasional yang buruk. Dari berbagai masalah yang membelit tenaga guru inilah yang kemudian berdampak pada minat menjadi guru semakin kecil, bahkan tidak jarang guru beralih profesi untuk mendapatkan kesejahteraan hidup yang lebih baik.

Guru yang berkeinginan untuk berganti profesi atau pindah tempat kerja dikenal dengan istilah intensi turnover. Menurut Robert, dan John ada beberapa penyebab mengapa seorang pegawai berkeinginan untuk keluar dari tempat kerjanya seperti ketidakpuasan kerja, upah, karir, pengawasan, geografi, dan alasan pribadi/keluarga serta adanya peluang karir diperusahaan lain.

Intensi turnover yang kemudian jika terjadi turnover oleh guru maka meberikan dampak bagi sekolah tersebut. Turnover yang terjadi merugikan bagi pihak sekolah atau yayasan baik dari segi biaya, sumber daya, maupun berdampak pada motivasi guru. Jika turnover terjadi berarti organisasi kehilangan sejumlah tenaga kerja. Kehilangan ini harus diganti dengan guru yang baru. Sebuah organisasi harus mengeluarkan biaya mulai dari perekrutan

${ }^{1}$ Guru SMP di Kecamatan Penjaringan, Pluit 
hingga mendapatkan pekerja yang siap pakai. Keluarnya pegawai berarti ada posisi tertentu yang lowong yang segera diisi. Selama masa lowong maka tenaga kerja yang ada kadang tidak sesuai dengan tugas yang ada sehingga terbengkalai, sementara guru yang berada dilingkungan tersebut terpengaruh motivasi dan semangat kerjanya.

Demikian halnya dengan guru di sekolah bercirikan Agama Buddha, terdapat keinginan oleh guru untuk meninggalkan pekerjaannya. Seperti yang disampaikan oleh humas Badan koordinasi pendidikan Buddhis (BKPB) DKI Jakarta, Bapak Wibi Sarono, menyatakan bahwa beberapa guru memiliki keinginan untuk berganti profesi, beralih pada profesi yang lebih baik secara finansial dan lebih menjanjikan. Meskipun demikian, banyak guru yang mengajar di sekolah pendidikan Buddhis memilih untuk bertahan, karena alasan belum mendapatkan tempat pekerjaan lain, atau takut jika tidak mendapat pekerjaan yang lebih baik.

Dewasa ini guru dituntut untuk bekerja ekstra keras oleh sekolah atau yayasan, seperti tambahan jam mengajar, guru terlibat dalam semua kegiatan sekolah atau yayasan, guru merangkap jabatan, dan tambahan mengajar privat atau les dan tambahan mengajar ekstrakulikuler lainnya, sementara itu guru merasa apa yang dilakukan tidak sebanding dengan apa yang terima dari pihak sekolah atau yayasan. Selain permasalahan tersebut, di sekolah bercirikan agama Buddha, masih banyak terdapat guru yang mengajar bukan pada bidang keilmuannya, misalnya guru dengan lulusan S1 Agama Buddha, mengajar pelajaran PKn, Bahasa Indonesia, Bimbingan Konseling dan lain sebagainya. Tentunya beban kerja semakin berat dirasakan ketika seorang guru mengajar bukan pada bidang ilmu yang dikuasai dan harus belajar dari awal lagi.

Beban kerja yang berlebihan berdampak secara fisiologis ataupun psikologis bagi seorang guru. Dampak fisiologis seperti, sakit kepala, lelah secara fisik, dan gangguan fisik lainnya. Sementara secara psikologis dapat berupa, hilangnya semangat, lesu, kurang bergairah, depresi, frustasi dan kejenuhan dalam bekerja.

Burnout (kejenuhan kerja) terjadi karena tuntutan pekerjaan serta pekerjaan tersebut merupakan sebuah rutinitas yang terjadi dalam jangka waktu yang cukup lama serta guru terlalu intens dalam pekerjaanya, sehingga orang tersebut mengalami kejenuhan yang memuncak. Guru adalah salah satu profesi yang dapat memicu burnout (kejenuhan kerja), hal tersebut terjadi karena profesi guru memiliki rutinitas seperti menghadapi siswa, mengerjakan tugas sekolah, mengoreksi tugas sekolah, mengelola kelas dan kegiatan lainya yang memicu rasa jenuh. Seperti yang dikemukakan oleh Hellriegel (2011:230) pekerjaan yang rentan dengan munculnya burnout (kejenuhan kerja)antara lain, tentara, perawat, polisi dan tenaga guru. 


\section{Intensi Turnover}

Sebelum melakukan pengunduran diri maka biasanya pegawai memiliki keinginan atau niat yang disebut intensi. Pengertian intensi secara sederhana adalah "niat seseorang untuk melakukan prilaku tertentu". Dalam banyak perjalanan kehidupan keinginan atau kehendak meberikan dorongan perilaku tertentu. Menurut Leek (2005:99), "many behaviors in everyday life, often the behaviors of greatest interest to personality and social psychologists, can be thought of as being largely under volitional control. That is to say, people can easily perform these behaviors if they are so inclined, or refrain from performing them if theydecide against $i t^{\prime \prime}$. Berdasarkan definisi tersebut menjelaskan bahwa banyak perilaku dalam kehidupan sehari-hari, sering dianggap suatu ketertarikan yang penting dalam sebuah kepribadian dan dalam psikologi sosial, yang dianggap sebagai sesuatu yang dikontrol oleh kehendak. Artinya, orang dapat dengan mudah melakukan sebuah tindakan jika mereka begitu menginginkanya, atau menahan diri dari melakukan sesuat, jika mereka memutuskan untuk menentang atau menahan diri.

Menururt Ricky W. Griffin (2014:80), "turnover occurs when people quit their jobs". Bedasarkan definisi tersebut bahwa Turnover merupakan ketika seorang pegawai keluar dari pekerjaannya. Intensi Turnover menggambarkan pikiran individu untuk keluar, mencari pekerjaan di tempat lain, serta keinginan meninggalkan organisasi. Keinginan yang berujung pada keputusan untuk keluar dari sebuah instansi atau organisasi terjadi karena individu mengalami sebuah ketidaknyamanan dalam bekerja. Seperti yang dikemukakan oleh Jessica A. Junak (2007:12), "turnover intention is considered as conscious and deliberate willingness to leave the organization". Berdasarkan definisi tersebut yaitu intensi turnover dianggap sebagai kemauan sadar dan terencana untuk meninggalkan organisasi. Robbins dan Judge (2012:373) mendefinisikan,"turnover is the voluntary and involuntary permanent withdrawal from an organization". Berdasarkan definisi tersebut menyatakan bahwa Turnover dibedakan menjadi dua tipe, yaitu turnover yang sukarela (voluntary turnover) yang diprakarsai pegawai dan tipe turnover yang terpaksa (involuntary turnover) yang diprakarsai organisasi.

Berdasarkan uraian dari beberapa sumber di atas dapat disintesiskan bahwa intensi turnover adalah keinginan seorang pegawai untuk meninggalkan pekerjaannya atas pertimbangan tertentu, secara sadar dan terencana, dengan indikator: (1) Kondisi pekerjaan tidak sesuai harapan (2) adanya keinginan untuk berhenti bekerja; (3) kondisi jadwal pelajaran tidak sesuai harapan, (4) mempertimbangkan pekerjaan di tempa lain(5) profesi yang tidak sesuai dengan keinginan 


\section{Beban Kerja}

Menurut Kepmenpan RI No. 75 tahun 2004 Beban kerja merupakan sejumlah target pekerjaan atau target hasil yg harus dicapai dalam satu satuan waktu tertentu. Dalam Permendagri No. 12 tahun 2008, Beban kerja merupakan besaran pekerjaan yang harus dipikul oleh suatu jabatan/unit organisasi dan merupakan hasil kali antara volume kerja dan norma waktu.

Menurut Steve M. Jex dan Thomas (2008:212), "Workload is typically defined as the amount of work an employee has to do in a given period of time". Beban kerja biasanya didefinisikan sebagai jumlah pekerjaan seorang pegawai yang harus dilakukan dalam jangka waktu tertentu. Menurut Jason A. Colquitt (2014:133)," workload is higher due to additional responsibilities that include receiving merchandise from vendors, taking physical inventory, and training new employees". Beban kerja yang tinggi diiringi dengan tanggung jawab yang tinggi, seperti halnya dengan guru dengan adanya tanggung jawab atau tugas tambahan maka beban kerja pun akan bertambah. Menurut Hellriegel dan John (2011:223), " workload for some employees, having too much work to do and notenough time or resources to do it is a major stressor". Beban kerja bagi pegawai merupakan sesuatu yang begitu banyak untuk dikerjakan dan tidak cukup waktu dan sumber daya atau kemampuan sehingga hal tersebut memicu pada stress.

Berdasarkan uraian di atas dapat disintesikan, Beban kerja adalah sejumlah tugas dan tanggung jawab pekerjaan yang dilakukan oleh pegawai dalam batasan dan jangka waktu tertentu. Beban kerja dengan dimensi kuantitatif memiliki indikator (1) banyaknya pekerjaan (2) tuntutan pekerjaan (3) tanggung Jawab pekerjaan, dan dimensi kualitatif dengan indikator (4) kemampuan bekerja (5) kesanggupan mengerjakan tugas.

\section{Burnout (Kejenuhan Keja)}

Gold dan Roth berpendapat (2013:373), " burnout is frequently cited as a syndrome of emotional exhaustion and cynicism occurring among human services professionals". Dapat didefinisikan bahwa burnout sering diartikan sebagai sebuah sindrom kelelahan emosional dan sebuah bentuk sikap sinis, yang terjadi diantara sikap manusia.

Menurut James L. Gibson (2011:205),"burnout is a psychological process, brought about by unrelieved work stress, which results in emotional exhaustion, depersonalization, and feelings of decreased accomplishment". Burnout adalah proses psikologis, yang dibawa oleh stres tak henti-hentinya bekerja, yang menghasilkan kelelahan emosional, depersonalisasi, dan perasaan prestasi menurun. Menurut Edwin Locke (2009:56), "burnout means that you no longer enjoy your job lack enthusiasm for it". Dapat didefiniskan yaitu bahwa burnout terjadi ketika seorang tidak lagi dapat menikmati pekerjaannya dan merasa tidak bersemangat atau antusias dengan pekerjaan tersebut.

Menurut George dan R. Jones (2008:249), "burnout is psychological, emotional, or physical exhaustion".Burnout adalah psikologis, emosional, atau 
kelelahan fisik. Lebih lanjut dijelaskan bahwa ada tiga tanda-tanda utama dari kelelahan ini yaitu, perasaan prestasi pribadi yang rendah, kelelahan emosional, dan depersonalisasi. Individu merasa tidak peduli lagi dengan orang lain, secara emosional mereka menjadi bergejolak.

Menurut Macey, Schneider, dan Barbera (2009:145) "burnout is most often thought of as a state of exhaustion, of being overwhelmed with, " no way out". Dapat didefinisikan bahwa burnout yang paling sering dianggap sebagai keadaan kelelahan, menjadi kewalahan dengan "tidak ada jalan keluar".

Berdasarkan pendapat para ahli di atas, dapat disintesikan burnout (kejenuhan kerja) adalah suatu kondisi kelelahan kerja secara, psikis dan fisik oleh pegawai yang terjadi pada tuntutan pekerjaan dalam jangka waktu tertentu. Dengan indikator, (1) kelelahan fisik, (2) Sikap sinis, (3) antusias bekerja menurun, (4) mudah menyerah (5) rendah diri (6) tidak menikmati pekerjaan.

\section{METODE}

Penelitian ini menggunakan metode survay dengan pendekatan kuantitatif-kausal dengan menggunakan analisis jalur (pathanalysis). Pola ini ini dimaksud untuk menganalisis pola hubungan antar variabel dengan tujuan untuk mengetahui pengarauh langsung maupun tidak langsung seperangkat vareabel bebas (eksogen) terhadap variabel terikat (endogen). Populasi terjangkau dalam penelitian ini adalah seluruh guru pada Sekolah Menengah Pertama (SMP) di sekolah bercirikan agama Buddha di DKI Jakarta dengan jumlah Guru 110. Dengan menggunakan rumus Slovin dengan menggunakan teknik acak sederhana (simple Random Sampling) diperoleh sampel sebanyak 92 guru. Pengumpulan data dalam penelitian ini adalah statistik diskriptif dan statistik inferensial.

\section{HASIL DAN PEMBAHASAN}

\section{Pengaruh Beban Kerja Terhadap Intensi Turnover}

Dari hasil pengujian hipotesis pertama dapat disimpulkan bahwa terdapat pengaruh langsung positif beban kerja terhadap intensi turnover dengan nilai koefisien korelasi sebesar 0,440 dan nilai koefisien jalur sebesar 0,339 . Ini memberikan makna beban kerja berpengaruh langsung positif terhadap intensi turnover.

Berdasarkan hasil penelitian diatas menunjukan bahwa terdapat pengaruh antara beban kerja dengan intensi turnover guru Sekolah Menengah Pertama (SMP) di sekolah bercirikan agama Buddha di DKI Jakarta. Seperti halnya fakta yang ada di lapangan bahwa guru mengalami beban kerja yang berlebihan, seperti halnya guru mengajar melebihi standar jam mengajar, guru terlibat diberbagai kegiatan yayasan dan sekolah, guru mengajar bukan pada bidang keahliannya, guru merangkap berbagai bidang mata pelajaran, serta guru juga mengerjakan administrasi tambahan selain administrasi mengajar, 
seperti membuat proposal kegiatan, membuat laporan pertanggung jawaban dan lain sebagainya.

Fakta lain menunjukan bahwa guru di sekolah swasta khususnya sekolah menengah pertama (SMP) di sekolah bercirikan agama Buddha di DKI Jakarta banyak sekali kegiatan sekolah yang menuntut keterlibatan guru, mulai dari perencanaan, pelaksanaan hingga evaluasi sebuah kegiatan. Kegiatan-kegiatan tersbut misalnya dalam sekolah bercirikan agama Buddha ada kegiatan seperti peringatan hari raya agama Buddha, bakti sosial, kegiatan pelatihan diri kegiatan pembinaan atau pengembangan diri baik guru maupun siswa dan kegiatan lainya yang diselenggarakan baik oleh yayasan ataupun oleh sekolah, yang semua kegiatan tersebut menuntut peran serta dan keterlibatan guru di sekolah tersebut.

Selain itu juga terlihat di bahwa yayasan memandang bahwa bagaimana memaksimalkan sumberdaya guru yang ada, dengan memaksimalkan kerja mereka dengan memberikan beban kerja semaksimal mungkin keguru tersebut, sementara guru merasa beban yang diberikan terlalu berlebihan. Hal tersebut dapat dilihat dimana seorang guru diberikan tugas yang begitu komplek, misalnya satu guru dapat merakap menjadi menjadi wali kelas, menjadi bendahara, menjadi pelaksana kegiatan, mengajar lebih dari satu mata pelajaran dan lain sebagainya. Hal ini juga sejalan dengan pendapat Maslach dan Leiter (1997:38) bahwa, cara pandang antara organisasi/perusahaan dengan pegawai akan beban kerja berbeda, yaitu;"workload is a key dimension of organizational life. From the organization's perspective, workload means productivity. From the individual 's perspective, workload means time and energy. Finding acompromise between the two perspectives is a fundamental challenge in a balanced relationship with work". Beban kerja jika dilihat dari persepektif organisasi, beban kerja merubakan sebuah produktivitas, artinya bahwa, semakain banyak beban kerja yang diberikan, maka tugas dan tanggung jawab akan segera terselesaikan, dengan berbagai cara untuk memaksimalkan tenaga kerja atau kemampuan dari pegawainya. Sementara itu dari perspektif pegawai beban kerja merupakan berkaitan dengan waktu dan tenaga.

Kondisi beban kerja tersebutlah yang kemudian memicu terjadinya intensi turnover. Yaitu adanya keinginan oleh seorang guru untuk berganti pekerjaan. Sebagai guru dengan beban kerja yang berlebihan dan begitu komplek akan memberikan dampak baik secara fisik maupun psikis, dimana pada akhirnya akan memicu terjadinya reaksi untuk berfikir memilih pekerjaan lain yang lebih sesuai antara apa yang dikerjakan dengan yang didapatkan. Seperti yang kita ketahui permasalahan kesejahteraan, imbalan, kompensasi dan beban kerja masih terjadi di dunia pendidikan di Indonesia, khususnya pada pegawai swasta

Berdasarkan fakta-fakta dilapangan tersebutlah yang kemudian beban kerja yang berlebihan berpengaruh terhadap intensi turnover guru Sekolah Menengah Pertama (SMP) di sekolah bercirikan Agama Buddha di DKI Jakarta. 


\section{Pengaruh Kejenuhan Kerja terhadap Intensi Turnover}

Dari hasil pengujian hipotesis kedua dapat disimpukan bahwa terdapat pengaruh langsung positif kejenuhan kerja terhadap intensi turnoverdengan nilai koefisien korelasi sebesar 0,427 dan nilai koefisien jalur sebesar 0,320. Ini memberikan makna kejenuhan kerja berpengaruh langsung positif terhadap intensi turnover.

Profesi menjadi guru tentunya akan berkaiatan erat dengan sebuah kejenuhan, dimana kondisi pekerjaan yang monoton dimana seorang guru akan menjumpai susana kelas yang sama, siswa yang sama, rutinitas pekerjaan yang sama, pekerjaan yang sama dalam intensi waktu tertenu akan menyembabkan sebuah kejenuhan. Kejenuhan kerja tentu akan berdampak pada sebuah keinginan seorang guru untuk mendapatkan susana pekerjaan dan pekerjaan yang baru.

Kejenuhan kerja akan memeberi dampak pada seorang guru dalam menjalankan tugas dan kewajibanya. Kejenuhan kerja yang dialami oleh seorang guru Sekolah Menengah Pertama (SMP) di sekolah bercirikan Agama Buddha di DKI Jakarta, akan memberikan dampak pada rasa nyaman, antusias dan motivasi dalam bekerja, hingga pada munculnya keinginan oleh seorang guru untuk berganti pekerjaan atau intensi turnover.Intensi turnover tesebut muncul dikarena adanya kejenuhan dalam bekerja, pekerjaan yang monoton dan tekanan serta rutinitas sebagai guru merupakan faktor timbulnya intensi turnover. Dengan adanya intensi turnover yang dialami oleh guru Sekolah Menengah Pertama (SMP) di sekolah bercirikan Agama Buddha di DKI Jakarta, tersebut akan tumbul keinginan mencari pekerjaan lain, mencari informasi tentang pekerjaan lain, membandingkan dengan pekerjaan, berusaha mencoba bekerja ditempat lain, yang kemudian hal tentunya akan berdampak pada kinerja dan produktivitas seorang guru. Seperti halnya pendapat Tenant dalam Sabine B. Koler (2013:27), menyatakan bahwa, "people at risk of burnout and work depression can contribute to worsening job performance, increased absenteeism and job turnover, decreased productivity, and can have a negative effect on coworkers". Dijelaskan bahwa Orang yang beresiko mengalami kejenuhan kerja dan depresi kerja dapat berakibat memburuknya kinerjanya, peningkatan absensi dannturnover, penurunan produktivitas, dan dapat memiliki efek negatif pada rekan kerjanya. Pendapat lainnya juga disampaikan oleh Colquitt (2014:143),"burnout, and the majority of them illustrate how burnout can lead to decision to quit a job or oven change careers". Dapat didefinisikan bahwa, burnout merupakan sebuah gambaran faktor utama seseorang untuk mengambil keputusan berganti atau meninggalkan pekerjaanya.

Berdasarkan uraian tersbut diatas dan di dukung dari pendapat beberpa ahli maka kejenuhan kerja berpengaruh pada intensi turnover guru Sekolah Menengah Pertama (SMP) di sekolah bercirikan Agama Buddha di DKI Jakarta. 


\section{Pengaruh Beban Kerja terhadap Kejenuhan Kerja}

Dari hasil pengujian hipotesis ketiga dapat disimpulkan bahwa terdapat pengaruh langsung positif beban kerja terhadap kejenuhan kerja dengan nilai koefisien korelasi sebesar 0,316 dan nilai koefisien jalur sebesar 0,316. Ini memberikan makna beban kerja berpengaruh langsung positif terhadap kejenuhan kerja.

Beban kerja yang diterima guru Sekolah Menengah Pertama (SMP) di sekolah bercirikan Agama Buddha di DKI Jakarta, yang yang telah diuraikan selain berdampak pada intensi turnover, juga berdampak pada kejenuhan kerja, hal tersebut dikarena bahwa beban kerja yang berlebihan, tuntutan pekerjaan yang komplek, tugas administrasi yang banyak, rutinitas mengajar yang monoton, beberapa jam berada dikelas akan berdampak pada kejenuhan kerja seorang guru. Hal tersebut juga diuraikan oleh Maslach dan Leiter (1997:26) bahwa, "Work overload was major factor from the beginning. Spent intense eight-hour days in the classroomand extra hours-after school, in the evening, and on weekends to prepare for class, grade homework. And attend meetin".Dari uraian di atas dapat didefinisikan bahwa, ada beberapa penyebab timbulnya burnout9 (kejenuhan kerja) pada guru akibat beban kerja yaitu; guru menghabiskan delapan jam hari di kelas danjam tambahan, mengerjakan tugas dimalam hari,dan diakhir pekan untuk mempersiapkan pekerjaan rumah (PR) dari kelas, dan menghadiri pertemuan.

Kejenuhan kerja yang dipengaruhi oleh beban kerja seorang guru ini muncul dimana tugas dan tanggung jawab yang diberikan tidak diimbangi dengan penghargaan yang diberikan. Selain itu juga pekerjaan sebagai seorang guru misalnya seperti menyiapkan tugas, mengoreksi hasil dari siswa, menyiapakn media pembelajaran, membawa pulang tugas tambahan, yang kemudian tidak ada waktu bagi seorang guru untuk menikmati waktu berlibur bersama keluarga yang karena tugas dan pekerjaan yang komplek yang kemudian memicu pada munculnya kejenuhan kerja.

Kejenuhan kerja merupakan suatu kondisi kelelahan kerja secara psikis dan fisik yang dialami oleh seorang guru yang terjadi pada tuntutan pekerjaan tertentu. Beban kerja yang dibebankan kepada seorang guru, dimana setiap beban kerja yang diberikan memiliki batasan waktu tertentu akan memeberikan tekanan dan desakan untuk diselesaikan, hal tersebut juga tentunya akan memicu kelelahan secara fisik dan psikis pada seorang guru.Berdasarkan uraian dari beberapa teori dan hasil penelitian tersebut di atas, dapat diketahui bahwa beban kerja memiliki pengaruh terhadap burnout (kejenuhan kerja)yang terjadi pada pegawai karena kondisi pekerjaan tertentu.

Berdasarkan uraian tersebut di atas, dapat diketahui bahwa beban kerja memiliki pengaruh terhadap kejenuhan kerjayang terjadi pada guru Sekolah Menengah Pertama (SMP) di sekolah bercirikan Agama Buddha di DKI Jakarta. 


\section{PENUTUP}

Kesimpulan: 1) beban kerja berpengaruh langsung terhadap posistif terhadap intenti turnover. Artinya peningkatan beban kerja mengakibatkan peningkatan intensi turnover guru Sekolah Menengah Pertama (SMP) di sekolah bercirikan Agama Buddha di DKI Jakarta. 2) kejenuhan kerja berpengaruh langsung positif terhadap intensi turnover. Artinya bahwa dengan kejenuhan kerja yang tinggi berakibat meningkatnya intensi turnover guru sekolah menengah pertama (SMP) disekolah bercirikan agama Buddha di DKI Jakarta. 3) beban kerja berpengaruh langsung positif terhadap kejenuhan kerja. Artinya bahwa dengan beban kerja tinggi berakibat pada meningkatnya intensi turnover guru Sekolah Menengah Pertama (SMP) di sekolah bercirikan Agama Buddha di DKI Jakarta.

Saran: 1) kepala sekolah atau yayasan perlu memperhatikan kemampuan dan kesanggupan seorang guru dalam melaksanakan beban pekerjaan, karena dengan beban pekerjaan yang tidak sesuai akan memberikan dampak terjadinya keinginan seorang guru untuk meninggalkan pekerjaannya, tentunya dengan adanya pemikiran atau keinginan seorang guru untuk meninggalkan pekerjaannya memberikan pengaruh pada konsentrasi dan kenyamanan seorang guru dalam menyelesaikan tugasnya. 2) dengan melihat hasil penelitian bahwa kejenuhan kerja berpengaruh langsung terhadap intensi turnover, maka seorang pimpinan harus membuat sebuah kebijakan yang dapat meminimalisi terjadinya kejenuhan kerja, dengan menciptakan lingkungan kerja yang menyenangkan, suasana kerja yang kondusif, serta meperhatikan tugas dan tanggung jawab rutinitas seorang guru yang dapat memicu terjadinya kejenuhan kerja. 3) kepala sekolah atau yayasan harus melihat dan mengkaji lagi mengenai tugas dan tanggung jawab yang diberikan kepada seorang guru, seorang guru swasta memiliki pekerjaan yang komplek mulai dari mengerjakan atministrasi pembelajaran, seorang guru swasta juga banyak terlibat dengan tugas-tugas tambahan dari sekolah sehingga jika hal ini tidak diperhatikan akan berdapak pada terjadinya kejenuhan kerja seroang guru.

\section{DAFTAR RUJUKAN}

Colquitt, A Jason, Jeffery A. LePine, Michael J. Wesson. Organizational Behavior Improving Performance and Commitment in the Workplace. New York : McGraw-Hill Education, 2014.

George M. Jennifer \& Gareth R. Jones. Understanding And Managing Organization. America: Pearson Education, 2008. 
Griffin W Ricky. Organizational Behavior Managing People And Organizations. Usa: South-Western, 2014.

Kep.Men.PAN Nomor: KEP/75/M.PAN/7/2004.BAB II.

Leek Ajzen. Attitudes, Personality And Behavior. New York: McGraw-Hill Education, 2005.

Locke Edwin. Handbook Of Principles Of Organizational Behavior_ Indispensable Knowledge For Evidence-Based Management. United Kingdom: Designs And Patents Act, 2009.

M. Stoner dan Kim, H. Burnout And Turnover Intention Among Social Worker: Effect Of Role Stress, Job Autonomy And Social Support. Administration In Social Work, 2008.

Macey H William. Employee Engagement: Tools for Analysis, Practice, and Competitive Advantage. United Kingdom:Blackwell Publishing, 2009.

Maslach Christina, Michael P. Leiter. The Trusth About Burnout. San Fransisco: Jossey-Bass, 1997.

Michael P. Leiter Christina Maslach. Banishing Burnout. San Francisco: JosseyBass, 2005.

R.A. Roth and Gold, Techers Managing Stress and Preventing Burnout. London: Taylor \& Francis, 2005.

Robert L. Mathis, John H. Jackson-Human Resource Management. USA: SouthWestern, 2011.

Robbins Stephen P dan Timothy A Judge, Organizational Behavior. New Jersey: Prentice Hall, 2012.

Slocum W. John dan Don Hellriegel, Jr. Organizational Behavior. USA:SouthWestern, 2011.

Steve M. Jex and Thomas W. Britt.Organizational Psychology. Canada: Simultaneously, 2008.

Williams Chuck, Management-third Edition: USA: Thomson South-West, 2009. 